\title{
INFLUENCE OF AIR POLLUTION IN AN URBAN AREA ON HOSPITAL ADMISSIONS FROM ACUTE MYOCARDIAL INFARCTION
}

\author{
Dimitrova T. ${ }^{1}$, I. Zlatarov ${ }^{2}$, N. Donchev ${ }^{3}$, A. Penev ${ }^{4}$, E. Tsankova $^{5}$ \\ ${ }^{1}$ Department of Medico-biological sciences, MU-Varna, ${ }^{2}$ Department of Hygiene and Disaster \\ Medicine, MU-Varna, ${ }^{3}$ Vascular Surgery, MBAL St. Anna, Varna, ${ }^{4}$ Intensive Cardiology, \\ MBAL St. Marina, Varna, ${ }^{5}$ Medical College - Varna
}

Reviewed by: Assoc. Prof. Sv. Georgiev

\begin{abstract}
It has been established that the episodes of huge atmospheric pollutions like the London fog of 1952 are responsible for an increased mortality, the larger part of which from cardiovascular events. Aim of the study is to investigate the relation between the levels of atmospheric pollutants and the frequency of hospital admissions from acute myocardial infarction (AMI) in the city of Varna. Five hundred and eighty five patients were investigated from those who were admitted to the Intensive Care Clinic of St Marina University Hospital in Varna with a diagnosis of acute myocardial infarction (AMI) in the period from December 2004 to December 2005. For the same period from October 2004 to December 2005 the relationship between the quality of the atmospheric air and the frequency of hospital admissions form AMI was investigated. For the investigated period from 1 October 2004 to 31 December 2005 a total of 585 persons were admitted for treatment at the ICC with a diagnosis of AMI, of which $393(67.2 \%)$ were men and $192(32.8 \%)$ were women. The mean age for them was $64.05+/-0.49$ years (from 18 to 93 years of age). The frequency of hospital admissions from AMI show statistically significant correlational subordinations with almost all studied atmospheric pollutants. The atmospheric pollution in urbanised inhabited areas should be taken as a risk factor for cardio-vascular diseases. Monitoring of the quality of atmospheric air provokes multidisciplinary prophylactic interest, including the needs of cardiologic prevention.
\end{abstract}

Key words: air pollution, acute myocardial infarction

It has been established that the episodes of huge atmospheric pollutions like the London fog of 1952 are responsible for an increased mortality, the larger part of which from cardiovascular events. After taking ecological and political measures the levels and nature of pollutants have been significantly altered but there is evidence that even the present 'low' levels cause health problems (9). A number of investigations show relation between early and late effects of pollution of the atmospheric air in cities with high level of urbanisation and increased risk of cardiovascular pathology (14-16). Bulgarian authors point out as cardio-toxic atmospheric pollutants hydrogen sulphide, lead and nitrogen dioxide $(1,6)$. The most recent investigations focus on the content of carbon monoxide, nitrogen oxides, sulphur dioxide, lead aerosols and particulate matter: inhalable and respirable fraction in the atmospheric air as an influencing

Address for correspondence:

T. Dimitrova, Dept. of Medico-biological sciences, Medical University of Varna, 55 Marin Drinov str., BG-9002, Varna

e-mail:tvd@mnet.bg factor for the frequency of hospital admissions and mortality from acute myocardial infarctions (15).

Aim: to investigate the relation between the levels of atmospheric pollutants and the frequency of hospital admissions from acute myocardial infarction (AMI) in the city of Varna.

\section{SETTING AND METHODS}

Five hundred and eighty five patients were investigated from those who were admitted to the Intensive Care Clinic of St Marina University Hospital in Varna with a diagnosis of acute myocardial infarction (AMI) in the period from December 2004 to December 2005. Questionnaires were used to investigate 210 of them on cardiovascular risk according to sex, age, family history and occupation. The data obtained from the medical documentation on laboratory and instrumental investigations were assessed: biochemical indicators in serum for overall cholesterol and triglycerides, blood sugar and liver enzymes, of the hospitalised patients. BMI was established using a standard formula. 
Dimitrova T., I. Zlatarov, N. Donchev ...

For the same period from October 2004 to December 2005 the relationship between the quality of the atmospheric air and the frequency of hospital admissions form AMI was in- of St Marina University Hospital in Varna for the registered newly hospitalised patients per each day. Samples were taken (three manually and one automatically) from four sta-

Table 1. Mean characteristics of the quality of the atmospheric air for the period October 2004 - December 2005

\begin{tabular}{|c|c|c|c|c|c|c|}
\hline & & $\mathbf{N}$ & Mean & SE & Min & Max \\
\hline \multirow{3}{*}{$\begin{array}{l}\text { 1. Stationary } \\
\text { points } \\
\text { "Cherno more" } \\
\text { (manually) }\end{array}$} & Total PM, $\mu \mathrm{g} / \mathrm{m}^{3}$ & 129 & 0,25 & 0,02 & 0,02 & 1,89 \\
\hline & $\mathrm{SO}_{2}, \mu \mathrm{g} / \mathrm{m}^{3}$ & 129 & $33,94 \pm 6,9$ & 6,9 & 0,00 & 443 \\
\hline & $\mathrm{NO}_{2}, \mu \mathrm{g} / \mathrm{m}^{3}$ & 129 & 29,015 & 3,39 & 0,00 & 308,2 \\
\hline \multirow{3}{*}{$\begin{array}{l}\text { 2. Stationary } \\
\text { points "Vl. } \\
\text { Varnenchik" } \\
\text { (manually) }\end{array}$} & Total PM, $\mu \mathrm{g} / \mathrm{m}^{3}$ & 130 & 0,1013 & 0,01 & 0,02 & 0,74 \\
\hline & $\mathrm{SO}_{2}, \mu \mathrm{g} / \mathrm{m}^{3}$ & 130 & 12,006 & 5,29 & 0,00 & 578 \\
\hline & $\mathrm{NO}_{2}, \mu \mathrm{g} / \mathrm{m}^{3}$ & 130 & 12,9377 & 1,35 & 0,00 & 64 \\
\hline \multirow{5}{*}{$\begin{array}{l}\text { 3. Stationary } \\
\text { points } \\
\text { "Batak"Str. } \\
\text { (manually) }\end{array}$} & Total PM, $\mu \mathrm{g} / \mathrm{m}^{3}$ & 270 & 0,0998 & 0,003 & 0,0070 & 0,343 \\
\hline & $\mathrm{PM}_{10}, \mu \mathrm{g} / \mathrm{m}^{3}$ & 268 & 55,7826 & 1,53 & 3,4 & 147 \\
\hline & $\mathrm{SO}_{2}, \mu \mathrm{g} / \mathrm{m}^{3}$ & 306 & 15,1956 & 1,12 & 0 & 102,1 \\
\hline & $\mathrm{NO}_{2}, \mu \mathrm{g} / \mathrm{m}^{3}$ & 306 & 7,759 & 0,596 & 0 & 58,15 \\
\hline & $\mathrm{Pb}$ & 83 & 0,02 & 0,009 & 0 & 0 \\
\hline \multirow{13}{*}{$\begin{array}{l}\text { 4. Stationary } \\
\text { points } \\
\text { "Yan Palah"Str. } \\
\text { (automatically) }\end{array}$} & $\mathrm{O}_{3}, \mu \mathrm{g} / \mathrm{m}^{3}$ & 409 & 38,4939 & 1,4 & 3,18 & 117,8 \\
\hline & $\mathrm{NO}, \mu \mathrm{g} / \mathrm{m}^{3}$ & 350 & 18,80 & 0,99 & 0,03 & 111,7 \\
\hline & $\mathrm{NO}_{2}, \mu \mathrm{g} / \mathrm{m}^{3}$ & 448 & 21,268 & 0,54 & 0,26 & 96,9 \\
\hline & $\mathrm{NO}_{\mathrm{x}}, \mathrm{ppm}$ & 218 & 24,7 & 0,989 & 0,52 & 94,04 \\
\hline & $\mathrm{SO}_{2}, \mu \mathrm{g} / \mathrm{m}^{3}$ & 277 & 32,34 & 0,91 & 2,19 & 67,46 \\
\hline & $\mathrm{CO}, \mathrm{mg} / \mathrm{m}^{3}$ & 296 & 1,014 & 0,03 & 0,13 & 4,1 \\
\hline & $\mathrm{PM}_{10}, \mu \mathrm{g} / \mathrm{m}^{3}$ & 238 & 4,67 & 0,76 & 0,00 & 87,58 \\
\hline & $\mathrm{NMHC}, \mathrm{mg} / \mathrm{m}^{3}$ & 375 & 1,0629 & 0,07 & 0 & 8,12 \\
\hline & $\mathrm{CH}_{4}, \mu \mathrm{g}-\mathrm{C} / \mathrm{m}^{3}$ & 59 & 1,4456 & 0,1 & 0,1 & 3,16 \\
\hline & $\mathrm{THC}, \mathrm{mg} / \mathrm{m}^{3}$ & 344 & 4,15 & 0,055 & 0 & 8,6 \\
\hline & $\mathrm{H}_{2} \mathrm{~S}, \mathrm{mg} / \mathrm{m}^{3}$ & 233 & 0,0028 & 0,00 & 0,00 & 0,01 \\
\hline & $\mathrm{NH}_{3}, \mathrm{mg} / \mathrm{m}^{3}$ & 251 & 0,0252 & 0,00 & 0,00 & 0,09 \\
\hline & Benzol, $\mu \mathrm{g} / \mathrm{m}^{3}$ & 52 & 1,3965 & 0,2 & 0,00 & 5,14 \\
\hline \multirow{5}{*}{$\begin{array}{l}\text { 5. Meteorological } \\
\text { parameters }\end{array}$} & Temperature, ${ }^{0} \mathrm{C}$ & 457 & 12,179 & 0,37 & -9 & 27,297 \\
\hline & Humidity, \% & 449 & 74,82 & 0,46 & 44,91 & 96 \\
\hline & Pressure, mbar & 457 & 1010,6 & 0,34 & 987,5 & 1032,7 \\
\hline & Radiation, W/m & 293 & 301,487 & 16,6 & 20,52 & 713,7 \\
\hline & Wind speed, $\mathrm{m} / \mathrm{s}$ & 457 & 1,718 & 0,03 & 0,73 & 4,62 \\
\hline
\end{tabular}

vestigated. Data from the Regional Inspectorate of Environment and Water and the Regional Inspectorate of Protection and Control of Public Health were analysed for the mean daily values of the concentrations of atmospheric pollutants, as well as data from the Intensive Care Clinic (ICC) tionary points on the territory of the city of Varna as part of a system for monitoring the quality of air. Only hospitalised citizens of Varna were included in the analysis.

For the statistical processing of the data the variational, descriptive and correlational analyses were applied. 


\section{RESULTS}

For the investigated period from 1 October 2004 to 31 December 2005 a total of 585 persons were admitted for treatment at the ICC with a diagnosis of AMI, of which 393 $(67.2 \%)$ were men and $192(32.8 \%)$ were women. The mean age for them was $64.05+/-0.49$ years (from 18 to 93 years of age).
Comparison of the results from the measurements taken during the period 1998-2005 and those from the period 1990-1997 do not show substantial alteration of the quality of the atmospheric air in the various parts of the municipality when compared to its state before 1998. After 1997, however, a certain decrease of the concentrations is observed as a whole and the stabilisation of the values is better expresses after 2000. For the period 2002-2005 a very

Table 2. Air pollutions with seasonal dynamics

\begin{tabular}{|c|c|c|c|c|}
\hline \multirow{2}{*}{\multicolumn{2}{|c|}{ Variable }} & Summer & Winter & $\mathbf{P}$ \\
\hline & & Mean S.E. & Mean S.E. & \\
\hline \multirow{5}{*}{$\begin{array}{l}\text { Stationary } \\
\text { points } \\
\text { "Batak"Str. }\end{array}$} & Total PM, $\mu \mathrm{g} / \mathrm{m}^{3}$ & $0,088 \pm 0,003$ & $0,11 \pm 0,004$ & 0,000 \\
\hline & $\mathrm{PM}_{10}, \mu \mathrm{g} / \mathrm{m}^{3}$ & $51,7 \pm 1,59$ & $59,2 \pm 2,4$ & 0,014 \\
\hline & $\mathrm{SO}_{2}, \mu \mathrm{g} / \mathrm{m}^{3}$ & $16,63 \pm 1,8$ & $13,93 \pm 1,4$ & 0,2 \\
\hline & $\mathrm{NO}_{2}, \mu \mathrm{g} / \mathrm{m}^{3}$ & $3,84 \pm 0,65$ & $11,19 \pm 0,9$ & 0,000 \\
\hline & $\mathrm{Pb}$ & $0,006 \pm 0,002$ & $0,035 \pm 0,01$ & 0,116 \\
\hline \multirow{13}{*}{$\begin{array}{l}\text { Stationary } \\
\text { points } \\
\text { "Yan Palah" Str. }\end{array}$} & $\mathrm{O}_{3}, \mu \mathrm{g} / \mathrm{m}^{3}$ & $38,64 \pm 1,97$ & $38,39 \pm 1,96$ & 0,928 \\
\hline & $\mathrm{NO}, \mu \mathrm{g} / \mathrm{m}^{3}$ & $13,19 \pm 0,7$ & $25,9 \pm 1,9$ & 0,000 \\
\hline & $\mathrm{NO}_{2}, \mu \mathrm{g} / \mathrm{m}^{3}$ & $18,03 \pm 0,499$ & $24,15 \pm 0,89$ & 0,000 \\
\hline & $\mathrm{NO}_{\mathrm{x}}, \mathrm{ppm}$ & $20,16 \pm 0,72$ & $36,77 \pm 2,5$ & 0,000 \\
\hline & $\mathrm{SO}_{2}, \mu \mathrm{g} / \mathrm{m}^{3}$ & $32,17 \pm 1,1$ & $32,77 \pm 1,63$ & 0,765 \\
\hline & $\mathrm{CO}, \mathrm{mg} / \mathrm{m}^{3}$ & $0,99 \pm 0,04$ & $1,057 \pm 0,05$ & 0,354 \\
\hline & $\mathrm{PM}_{10}, \mu \mathrm{g} / \mathrm{m}^{3}$ & $0,0046 \pm 0,0007$ & $6,04 \pm 0,96$ & 0,000 \\
\hline & NMHC, $\mathrm{mg} / \mathrm{m}^{3}$ & $1,6 \pm 0,15$ & $0,73 \pm 0,04$ & 0,000 \\
\hline & $\mathrm{CH}_{4}, \mu \mathrm{g}-\mathrm{C} / \mathrm{m}^{3}$ & $0,966 \pm 0,14$ & $1,879 \pm 0,09$ & 0,000 \\
\hline & $\mathrm{THC}, \mathrm{mg} / \mathrm{m}^{3}$ & $4,01 \pm 0,1$ & $4,2 \pm 0,06$ & 0,054 \\
\hline & $\mathrm{H}_{2} \mathrm{~S}, \mathrm{mg} / \mathrm{m}^{3}$ & $0,0035 \pm 0,0002$ & $0,0013 \pm 0,0001$ & 0,000 \\
\hline & $\mathrm{NH}_{3}, \mathrm{mg} / \mathrm{m}^{3}$ & $0,027 \pm 0,001$ & $0,02 \pm 0,001$ & 0,005 \\
\hline & Benzol, $\mu \mathrm{g} / \mathrm{m}^{3}$ & $0,41 \pm 0,17$ & $1,48 \pm 0,21$ & 0,001 \\
\hline
\end{tabular}

The highest frequency of AMI cases was at the ages of 70 $(5.1 \%), 55(4.1 \%)$ и $65(4.1 \%)$. The mean age of men was 62.150 .569 years and it was significantly lower that that of women - 67.930 .855 . . (when $\mathrm{t}=5.723 \mathrm{p}<0.001)$.

Prevalent were the cases of AMI at the age from 65 to 75 . However, most than half $(51.6 \%)$ of all cases were in an active age for work. AMI was experienced by $60.6 \%$ of the men and $33.3 \%$ of the women before retirement age (X square $=38.286, \mathrm{p}<0.001$ ). The male sex is associated with higher risk of AMI at an active age 3.071 (95\% CI 2.139-4.410 при $\mathrm{p}<0.001)$. slight increase of the values of the parameters is detected as well as continuation of the tendency for increase of dust concentrations in the atmospheric air on the territory of the municipality. The other controlled pollutants are significantly below the permissible norms at all points (Table 2). It should be emphasised, however, that the stabilisation of the air is at certain times disrupted and in isolated cases peak values are observed, which not only exceed the order of the background regime, but also the threshold level of concentration of the respective pollutants. The excesses of the norms are observed also at the monitoring points of the 
Regional Inspectorate of Environment and Water in Varna on the particulate matter, sulphur and nitrogen oxides. At the point on Batak Street for the first half of 2004 there were registered 43 cases of excess of the mean daily norms for the quality of atmospheric air in inhabited areas on the parameter of fine particulate matter (PM10) and 8 cases on the parameter of general particulate matter. In comparison to the same period in previous years a $49 \%$ increase of the content of fine particulate matter was observed and a $13 \%$ increase of general particular matter. Based on data from the Regional Inspectorate of Environment and Water in Varna the mean concentrations for the first half of 2004 of the parameter of fine particulate matter in the city of Varna $\left(61.9 \mathrm{~g} / \mathrm{m}^{3}\right)$ exceed the annual limit (the annual average of the threshold level of concentration is $42 \mathrm{~g} / \mathrm{m}^{3}$ ) which is 1.47 times the annual average of the threshold level.

In 1999 the Ministry of Protection of the Environment and Waters and the Ministry of Health issued Regulations No. 8 on the norms for ozone in the atmospheric air (3) and Regulations No. 9 on the norms for sulphur dioxide, nitrogen dioxide, fine particulate matter and lead in the atmospheric air (4). These Regulations alter the amount of permissible concentrations of the respective pollutants as compared to those from Regulations No. 14 on the norms for the utmost limit of permissible emissions of deleterious substances in the atmospheric air of inhabited areas (5).

The comparison of the current state of the air on the territory of Varna Municipality with the norms from the altered Regulations shows that in future, even if there is no increase of pollution, there will be observed an increase of the number of cases with excess concentration of pollutants like sulphur dioxide, nitrogen dioxide, fine particulate matter, as compared to the currently observed exceeding of the norms. No information has been supplied by the Regional Inspectorate of Environment and Water and the Regional Inspectorate of Protection and Control of Public Health, Varna Municipality, the District administration and the Civil Guard on accidents leading to emission of deleterious substances in the atmospheric air (Table 1).

On the basis of mean monthly values of the meteorological parameters and mainly of the temperature of the air, the investigated period was divided into a warm (from May to October) and a cold (from November to April) half-period. Seasonal dynamics defined on the basis of statistically significant differences between the mean values for warm and cold annual half-period is established for most of the studied pollutants. The exceptions are the sulphur dioxide, lead aerosols, ozone, carbon oxide and common hydrocarbons. Summer peaks in the dynamics are the concentrations of non-methane hydrocarbons, hydrogen sulphide and ammonia. Statistically significantly higher are the concentrations in the winter half-period of the particulate matter, nitrogen oxides, methane hydrocarbons and benzene (Table 2).

The dynamics of the mean monthly frequencies of hospital admissions from AMI during the studied period shows maximum frequencies total of AMI for Varna citizens in November, December and October both in 2004 and in 2005. For person in active age this dependence is retained drawing attention to the relatively higher frequency of hospital admissions in August. The most affected age group of Varna citizens of 55 to 65 years shows a peak in the AMI frequency in December 2005, followed by August 2005, November 2004 and April 2005.

The AMI frequency among citizens of Varna working to particulate matter exposure shows peak values in June 2005, followed by February, April and September 2005. The highest number of cases of myocardial infarction in citizens working in conditions of hypokinesia, are registered in August and December 2005, followed by the November months both in 2004 and in 2005.

Statistically significant seasonal dynamics are established in the frequency of hospital admissions among citizens of Varna (an average of 1.070 .038 cases daily in winter against 0.830 .07 in summer, $\mathrm{p}<0.05)$, in men (0.75 0.058 against $0.530 .05 \mathrm{p}<0.05)$ and in elderly people. Cases of AMI in persons with excess cholesterol (0.36 0.04 cases daily in summer as against 0.580 .05 cases daily in winter half-periods $\mathrm{p}<0.05)$ and triglycerides $(0.390 .04$ against $0.270 .04 \mathrm{p}<0.05$ ) also show significantly reliable differences in both half-periods. During the cold months AMI occurs more often. Apart from the levels of pollution of the atmospheric air, the investigations associate this fact with the higher respiratory morbidity during that period of the year (10). The mechanisms that explain these relations include changes in the immunity and the coagulation status. The frequency of hospital admissions from AMI show statistically significant correlational subordinations with almost all studied atmospheric pollutants. Most susceptible are the pensioners. Their susceptibility is highest in the cold months of the year where positive correlations with the levels of all atmospheric pollutants are observed, with the exception of lead aerosols, ozone and ammonia. Hospital admission in active age show the strongest correlation with the concentrations of methane hydrocarbons, carbon oxide, nitrogen oxides in total and particulate matter with diameter of up to 10 microns, and those correlations increase in winter months.

Nitrogen dioxide $\left(\mathrm{NO}_{2}\right)$ in all studied months demonstrates positive correlational coefficients with hospital admissions from AMI. The relation with this gas pollutant is widely investigated with relevance to cardiovascular diseases. In some cases there is strong dependence (13) while in others the effect depends on the other pollutants (8). Increased risk of coronary mortality was found in regions with high levels of nitrogen oxide, representative for pollution coming from the transport. If this cause and effect relation is accepted, then $6 \%$ of the mortality from ischaemic heart disease should be explained with the levels of nitrogen oxide (12). In our conditions through the models of independent influence of the atmospheric concentrations of nitrogen oxide it was established their strongest influence on hospital admissions in the whole group (correlational coefficient 0.564 ), for those working in conditions of hypokinesia $(0.538)$ and those performing mainly physical labour (0.476).

The interaction of the atmospheric pollution with sulphur dioxide $\left(\mathrm{SO}_{2}\right)$ and the frequency of AMI is best expressed 
in winter months. In October 2004 the correlational coefficients are from 0.759 for AMI in persons working overtime, 0.548 in persons working under stress, and in November 2004 it is up to 0.750 for AMI in persons of mental work. The highest dependence is in November and December 2005 when we find a correlation of 0.930 for AMI in active age, 0.643 for AMI in persons working under stress for November, and 0.827 for AMI for Varna citizens and 0.840 for AMI in persons in active age in December. The investigations, which include sulphur oxide, publish a variety of results. In some there is an absence of a significant association of that pollutant with cardiovascular morbidity $(7,11,17)$, while others show a $2 \%$ increase of the risk when levels increase by $10 \mu \mathrm{g} / \mathrm{m}^{3}(20)$. In many publications the importance of sulphur oxide visibly decreases or even disappears when the other pollutants are taken into consideration in the describing model of influence (19). Experimental investigations establish that the exposure is accompanied by an increase of general lipids, beta-lipoproteins and fatty acids when the activity of beta- lipoproteidlypasis in the serum is suppressed (2).

\section{CONCLUSIONS}

The atmospheric pollution in urbanised inhabited areas should be taken as a risk factor for cardio-vascular diseases. Monitoring of the quality of atmospheric air provokes multidisciplinary prophylactic interest, including the needs of cardiologic prevention.

\section{REFERENCES}

1. Басмаджиева К., М.Аргирова, Б.Никифоров, С.Табакова, Й.Калпазанов, Оценка на връзката на атмосферното замърсяване и здравето на населението, Хигиена и здравеопазване, 1986, 4, 49-53

2. Златева М., Иванович Е., Антов Г., Сърдечно-съдова система и производствение фактори, Медииина и физкултура София 1984

3. Наредба № 14 за норми за пределно допустими емисии на вредни вещества в атмосферния въздух на населените места

4. Наредба № 8 за норми за озон в атмосферния въздух

5. Наредба № 9 за норми за серен диоксид, азотен диоксид, фини прахови частици и олово в атмосферния въздух

6. Никифоров Б, Хигиенно-епидемиологични и токсикологични проучвания на рисковото значение на атмосферното замърсяване в НРБ за възникването и разпространението на сърдечно-съдовите заболявания. Докт. Дис С 1988

7. Anderson HR, Bremner SA, Atkinson RW, et al. Particulate matter and daily mortality and hospital admissions in the West Midlands conurbation of the United Kingdom: associations with fine and coarse particles, black smoke and sulphate. Occup Environ Med 20

8. Atkinson RW, Bremner SA, Anderson HR, et al. Short-term associations between emergency hospital admissions for respiratory and cardiovascular disease and outdoor air pollution in London. Arch Environ Health 1999;54:398-411

9. Barclay, Justin; Hillis, Graham; Ayres, Jon, Air Pollution and the Heart: Cardiovascular Effects and Mechanisms., Toxicological Reviews. 24(2):115-123, 2005.

10. Clayton T, Thompson M, Meade T, Recent respiratory infection and risk of cardiovascular disease: case-control study through a general practice database, European Heart Journal Advance Access published online on December 6, 2007

11. Lippmann M, Ito K, Nadas A, et al. Association of particulate matter components with daily mortality and morbidity in urban populations. Research Report Health Effects Institute 2000;95:5-72

12. Maheswaran R, Haining R P, Brindley $\mathrm{P}$, Law J, Pearson T, Fryers P R., Wise S and Campbell M J., Outdoor air pollution, mortality, and hospital admissions from coronary heart disease in Sheffield, UK: a small-area level ecological study, European Heart

13. Morgan G, Corbett S, Wlodarczyk J. Air pollution and hospital admissions in Sydney, Australia, 1990 to 1994. Am J Public Health 1998;88:1761-6

14. Pelham T W., Holt L E., Moss M A., Exposure to carbon monoxide and nitrogen dioxide in enclosed ice arenas, Occup Environ Med $2002 \mathrm{Apr}$ 01;59(4):224-233

15. Peters A, Dockery DW, Muller JE, Mittleman MA. Increased particulate air pollution and the triggering of myocardial infarction. Circulation 2001;103:2810-2815

16. Pope CA, III, Burnett RT, Thun MJ, et al. Lung cancer, cardiopulmonary mortality, and long-term exposure to fine particulate air pollution. JAMA 2002; 287: 1132-41.

17. Schwartz J. Air pollution and hospital admissions for cardiovascular disease in Tucson. Epidemiology 1997;8:371-7

18. Spengler JD, Stone KR, Lilley FW. High carbon monoxide levels measured in enclosed skating rinks. Journal of the Air Pollution Control Association 1978;28:776-9.

19. Sunyer J, Ballester F, Tertre. et al The association of daily sulfur dioxide air pollution levels with hospital admissions for cardiovascular diseases in Europe (the Aphea-II study). Eur Heart $J$ 2003;24:752-60

20. Wong TW, Lau TS, Yu TS, et al. Air pollution and hospital admissions for respiratory and cardiovascular diseases in Hong Kong. Occup Environ Med 1999;56:679-83 